\title{
A Comparative Study on Performance of Open and Close-ended Mutual Funds in Pakistan
}

\author{
${ }^{1}$ Waqas Ahmad, ${ }^{2}$ Muhammad Sohaib Roomi, ${ }^{3}$ Muhammad Ramzan \\ Department of Business Administration, Faculty of Management Science National Textile \\ University, Faisalabad Punjab, Pakistan
}

Email: ${ }^{1}$ waqasntu5059@gmail.com, ${ }^{2}$ ranaroomi66@gmail.com, ${ }^{3}$ ramzan_ntu@live.com

Muhammad Zia-ur-Rehman

Department of Business Administration, Faculty of Management Science National Textile

University, Faisalabad Punjab, Pakistan

\begin{abstract}
Sajjad Ahmad Baig (Corresponding author)
Assistant Professor, Department of Business Administration, Faculty of Management Science

National Textile University, Faisalabad Punjab, Pakistan

Email: sajjad.baig@ hotmail.com
\end{abstract}

Accepted: June 09, 2015

DOI: 10.5296/ijafr.v5i1.7487 URL: http://dx.doi.org/10.5296/ ijafr.v5i1.7487

\begin{abstract}
This paper is based on the comparison of Pakistani open-ended and close-ended mutual funds performance. That study focus on income, balance and equity schemes of open-ended and close-ended mutual funds. The performance of these funds evaluates using Sortino measure, Shrape measure, Treynor measure, Jenssen differtial measure and Inforamtion measure. The sample for the study consists of 73 funds from 2007 to 2012. Results show open-ended mutual funds performance is better than close-ended mutual funds. KSE (market portfolio) performance is grater over the all sample base mutual funds. Most risk adjusted funds returns are negative, which probably due to mutual fund industry set back by financial crisis during sample period.
\end{abstract}

Keywords: Open-ended Mutual Fund, Close-ended Mutual Fund, KSE 100, Risk Free Rate, Risk Adjusted Performance. 


\section{Introduction}

Mutual fund is an investment scheme which collects funds from investors and invests in different securities (stock, bond, money market instruments and comparable assets) for the purpose of reducing risk and increasing profits and returns (Bilal \& Shah, 2011). For individuals institutional investors and banks; mutual funds work as investment medium. The earned incomes from these funds are divided on the total unit owners. Many benefits of mutual funds but the best one is that in which mutual fund provide the facility to small investors to invest in diversified portfolio of equity, debt, TFCs and government securities and other securities. Without mutual funds it is quite difficult to make diversified portfolio with small amount. Mutual funds get attraction due to many other benefits like liquidity, variety, convenience diversification and professionally managed for investing in different securities.

Liquidity mean sell units easily, close funds at market and open funds to company at net assets value. Diversification means different investment opportunities like portfolio and minimize risk (put the eggs in many baskets). Investor risk minimize with diversification of portfolio. Make a mutual fund type investment is difficult task for average investors.

Variety means different kind of mutual funds. In all over the world there are different kinds of investor who want different level of risk and return, so managers make different variety of funds in the emerging market of mutual funds. Like Equity Scheme, Balanced Scheme, Asset Allocation fund, Fund of fund Scheme, Shariah Compliant (Islamic) Scheme, Capital Protected Scheme, Index Tracker Scheme, Money Market Scheme and Income Scheme etc.

Easily available and invest in mutual funds which makes them convenience. Funds shares/units are easily purchased and sale directly by emailing, via internet and through banks, brokers and insurance agents. Mutual funds are survived on the base of professionally managed companies whose managers have eagle eyes, who get complete benefit from any opportunity arises in the market. They take decision after carefully examines the opportunity, that is not an easy task for an individual any company who's basic business is not investing.

Basically two types of Mutual Funds on the basis of structure and funds offer for customers on demand or variety basis like Open-ended mutual funds and Close-ended mutual funds.

Open-Ended Mutual Funds

Open-ended means easily sell back to company at Net Asset Value (NAV). These funds not sell in secondary market, that funds continually create new units on demand. They are also called unit trust. These funds are in different verities and these units can be easily purchased and resold to fund Management Company which offers unit value (prices) daily. If any open-ended fund holder wants to sell its fund, he will sell those units to the company at present market price (NAV) and company obliged to buy units from unit holder at present price. Open-ended funds price decided on the bases of net assets value of fund Management Company. Net asset value is the difference of total asset and liability then remaining amount is divided on number of shares, which is calculated at the end of each treading day. The price of open-ended fund is equal to NAV that was not decided at supply and demand conditions like market price.

Close-Ended Mutual Funds 


\section{Mll Macrothink}

International Journal of Accounting and Financial Reporting ISSN 2162-3082 2015, Vol. 5, No. 1

Close-ended funds having shares like a public company. Close-ended funds issue fixed number of shares and floated through an IPO (initial public offering) same as public company. After issuance of shares close-ended fund traded in stock exchange also called secondary market with an agreed number of shares. Secondary market gives a place for investors to buy and sell units of mutual funds easily, these funds are traded in stock market like other companies shares. Same like other stocks value the funds value also decided on market forces supply, demand and fund's performance. There are many features of close-ended funds like; small amount of investment and diversification also possible, expertise of managers and market knowledge helpful for all types of mutual fund investors, investor easily buy and sell their units at any time at stock exchange and at low trading cost at stock exchange.

Investment wise there are different types of mutual funds. Professionally managed and diversification of fund is the main purpose which provide benefits to investor. All investor do not want same kind of fund due to different objectives. So mutual fund companies provide convenience and different verities for different types of investors in mutual fund schemes. In Pakistan mutual funds also available in different varieties which describe further.

Asset Allocation Funds Scheme invests in all categories of securities that gives diversifies or minimizes the risk for investment. All types of securities or assets choose for investment due to create a specific portfolio which reduce risk with the help of maximum diversification. In this portfolio all those assets are selected which maintenance cost are low. The purpose of portfolio to make for keeping in view the investors need is risk minimizing. Manager select different types of securities like government securities, stocks of different domestic and foreign companies and other investment types. Wide range of securities is available at a single plate form which saves time money and risk of wrong investment. Assets allocation fund scheme available in both open and close-ended mutual funds schemes.

All types of mutual funds helpful for investor to invest in any kind of investment according to their diversification set risk level return and amount of investment. Some kind of investors wants higher returns so they invest in Equity Fund for long period. Desire of investors is different some investor desire to get reasonable return they invest in Money Market fund and some want stream of money at fixed time period so they invest in Bonds funds etc.

The mutual fund industry follows the rules of Security and Exchange Commission of Pakistan (SECP) and trade body namely Mutual Funds Association of Pakistan (MUFAP). The Foreign and home Investor's confidence increasing due to the presence of these two government bodies. In 2012 the present mutual funds industry of Pakistan consists of 204 listed funds, out of these 155 are open ended funds, 9 are closed ended and 40 are pension funds. These funds are managed by 27 asset management companies (MUFAP 2012).

In these days investment strategies are change like individual and companies invest in debt and equity securities not in bank loans and their interest in mutual funds investment also increase. But Pakistan has not strong market as compare to other developed countries and global market. Due to taxes and less opportunity of saving in Pakistan, the saving ratio was low at $13.8 \%$ which show in Pakistan Economic Survey, 2010-11. 


\section{Macrothink}

\subsection{Significance of Study}

2015, Vol. 5, No. 1

In today's world not anyone economy denied mutual funds importance because mutual funds are now the new pillories of economies. So the mutual funds evaluation and comparison is very important on the fund's types bases like open and close-ended mutual funds which based on risk and return. Investors compare funds and also check the fund's manager performance on the bases of historical performance evaluation and cross-sectional comparison. Comparison and evacuation show who much return generated and how much risk taken for such funds return. The lack of evidence in this regards especially comparison between mutual funds in Pakistan show the vast considering to conducting research in this area. The importance of this issue force to choose the topic keeping in view of mutual funds performance comparison on the bases of open or close-ended mutual fund's performance is best. The purpose of the current study is to analyze the performance of open and close-ended mutual funds in Pakistani context.

\subsection{Objectives}

1. To evaluate and compare the performance of open-ended \& close-ended mutual funds of Pakistan.

2. To explore and compare the Risk (Market Risk, Total Risk) level of open-ended \& close-ended Mutual Funds of Pakistan.

3. To evaluate and compare the performance of open-ended mutual funds with market KSE 100 index of Pakistan.

4. To evaluate and compare the performance of close-ended mutual funds with market KSE 100 index of Pakistan.

\section{Literature Review}

For the purpose to see which fund are batter then other, so many thesis reports, many articles, annual reports, newspapers and economical survey find. All around the world mutual funds comparison performance reveal different results which show further in literature review.

Sharp (1966) developed such technique helpful for investors to evaluate mutual fund performance.

According to sharp the mutual fund performance determine by taking the average excess return divided on risk. He told funds carry more risk if the fund's portfolio is more volatile.

A study conducted by Jensen (1968), he developed a technique which assess the risk adjusted performance of mutual funds that is called Jansen Alpha. He also gave good suggestion for the investors which helpful for making investment decision that base on the cost benefits analysis.

Another study also found same situation as small funds slightly better than the large funds by Gorman (1991).

Fama and French (1993) and Carhart (1997) worked on asset pricing, they also described in their work that traditional one factor model to account for time varying style of funds managers investing in the stock market. Their common consensus was that the mixed ability of funds to outperform the market for the case developed world. This is a most effective technique for the evaluation. Nazir et.al, (2010) worked on 13 family equity funds from 2005 


\section{Ml Macrothink}

International Journal of Accounting and Financial Reporting ISSN 2162-3082 2015, Vol. 5, No. 1

to 2009. They find out the direct relation of asset turnover, family proportion, and expense ratio with growth of mutual fund, risk adjusted returns and management fee inversely. Bryant \& Liu, (2011) fund will be managed by multiple managers then risk will be higher than objectives of fund. Although the intention to bring of doing so it to bring down cost of management so that economies so scale can be achieved.

Nafees \& Sulman (2011) conducted a research on of close and open-ended mutual funds of Pakistan which evaluate the risk by using two measures ARCH (Autoregressive Conditional Hetroskedasticity) and GARCH (Generalized Autoregressive Conditional Hetroskedasticity) models. Sample size of 2006 to 2011 and result determined from statistical measures and $\mathrm{ARCH}$ and GARCH also show that closed end funds are more risky than open end and capital market.

Amir et.al, (2011) conducted research at mutual funds from 2001 to 2008. They work on mutual funds with different variables like paid up capital, market capitalization and KSE index to find their health, and also compare mutual funds with KSE. At the result shows mutual funds get more growth from KSE, and still lot of space for more development.

Gohar et.al, (2011) conducted research at different kind of Pakistani mutual fund. They show income funds less performs than equity funds. They also ravelled that initially equity broker backed security very well then income funds.Ali et.al, (2012) conducted study on mutual funds of Pakistan from 2005 to 2009 and select 15 mutual funds for analysis. They use Sharp and Treynor measure for data analysis. Result of the study ravels that market well performs then mutual funds.

So, it can be concluded that there are waste are of research on mutual fund and there are mixed results in evaluating the management effectiveness related to risk and returns of open-ended and close-ended mutual funds in Pakistan for the purpose of benefiting the fund's managers and the investors.

\section{Hypothesis}

The hypothesis develops in the study are as under:

$\mathrm{H}(0)$ Average Return of open-ended mutual funds is not greater than average return of close-ended mutual funds.

$\mathrm{H}(0)$ Average Return of open-ended mutual funds is not greater than average return of Market KSE 100 index.

$\mathrm{H}(0)$ Average Return of close-ended mutual funds is not greater than average return of Market KSE 100 index.

$\mathrm{H}(0) \quad$ Open-ended Mutual Funds are not more diversified to eliminate risk as compare to close-ended fund. 


\section{MInstitute"mk}

International Journal of Accounting and Financial Reporting

ISSN 2162-3082

2015, Vol. 5, No. 1

\section{Research Methodology}

\subsection{Population \& Sample size}

In 2012 mutual funds industry of Pakistan consists of 204 listed funds (MUFAP 2012). The sample will be consisted of 73 funds open and close ended mutual funds. Sample data was taken only from income, balance and equity schemes of open-ended and close-ended mutual funds offer in Pakistan. This study will be based on 6 year period i.e. 2007 to 2012 .

\subsection{Sources of Data}

Secondary data of mutual funds will be collected annually, from different websites like Mutual Fund Association of Pakistan (MFAP), Bloomberg, Business Recorder and Karachi Stock Exchange (KSE).

\subsection{Data Analysis Techniques}

Fives measures will be used for performance evaluation and comparison of mutual funds for both open and close ended funds:

1. Sortino measure 2. Sharpe's Ratio 3. Treynor's Ratio 4. Jenson's Measures 5. Information measure

\section{Results}

Figure.1 show average return of all close-ended, open-ended fund returns, market return and risk free rates. Average risk free rate is higher from all market, open and close-ended funds. Open-ended average fund's return is greater than close-ended funds return.

Figure 4.1

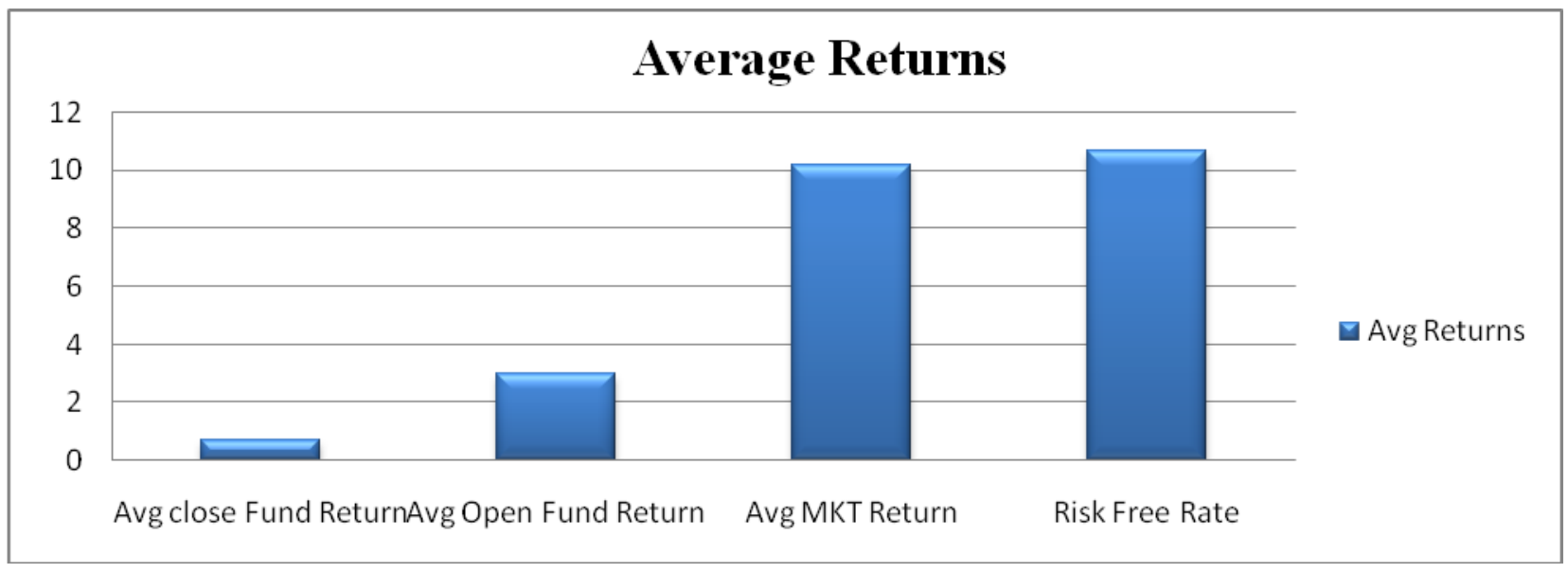

It is observing from figure-4.1 that open-ended equity fund six year average return is $6.75 \%$ and close-ended fund average return is $1.99 \%$, which show equity funds get more returns. The close-ended balance fund average return $-0.69 \%$ is lower among all funds but open-ended balance fund average return is $1.87 \%$. Average six year market return is $10.208 \%$ is higher from all average fund return in sample, but risk free average rate $10.67 \%$ is more than market and fund returns.

Market return $24.88 \%$ in 2007 higher from all return in sample size, risk free rate is $9.0 \%$ in 2007. Open-ended equity funds return $11.81 \%$ secondly higher returns in sample in 2007 


\section{Macrothink}

International Journal of Accounting and Financial Reporting ISSN 2162-3082 2015, Vol. 5, No. 1

from other open and all close-ended funds. Open-ended income funds return $1.109 \%$ lowest returns in sample in 2007 from other average open and all close-ended funds returns. In 2008 all funds return in negative and highest market negative return is $-58.16 \%$. Open-ended equity funds returns on second $-56.24 \%$ returns. Income close-ended funds return $-0.37 \%$ which is the higher return from all other funds returns. Risk free rate is the highest return $11.5 \%$, from all other funds and market returns in 2008.

In 2009 all funds return are in positive returns especially balance and equity fund types show more returns, but income show less returns. Market return is higher $74.56 \%$ and risk free return is $12.5 \%$. Open-ended equity funds return is $45.62 \%$ which higher from all other funds. Income close-ended funds return $0 \%$ and income open-ended return 3.07\% these are the lower return from all other funds returns. Open and close Balance fund returns and also open income fund are negative in 2010 . Highest return $4.31 \%$ of close-ended equity fund among all funds and secondly open-ended equity fund return $1.25 \%$. Market returns greater than others $25.05 \%$ and secondly risk free rate $12.0 \%$.

In 2011 all fund returns and market return are negative, but risk free rate is $9.0 \%$. Close-ended equity fund $-24.75 \%$ and open-ended equity fund $-16.6 \%$ returns are lesser among all funds returns. Close-ended equity fund $42.49 \%$ and open-ended equity fund $32.83 \%$ returns are higher among all funds returns, market return $3.11 \%$ and risk free rate $10 \%$ in 2012. Income open and close-ended fund return are lower among all funds, market and risk free rate

Six years average returns of Open-ended Mutual Fund is $2.979 \%$ more than the average return of Close-ended Mutual Fund $0.7149 \%$, but both funds average return $1.85 \%$ are less then market average return $10.208 \%$. But the average six year risk free rate $10.67 \%$ is greater than average market and funds return (Table -1$)$.

\begin{tabular}{|c|c|c|c|c|c|c|c|c|}
\hline Years & $\begin{array}{c}\text { Balance } \\
\text { Close Fund }\end{array}$ & $\begin{array}{c}\text { Balance } \\
\text { Open Fund }\end{array}$ & $\begin{array}{c}\text { Equity } \\
\text { Close Fund }\end{array}$ & $\begin{array}{c}\text { Equity } \\
\text { Open Fund }\end{array}$ & $\begin{array}{c}\text { Income } \\
\text { Close Fund }\end{array}$ & $\begin{array}{c}\text { Income } \\
\text { Open Fund }\end{array}$ & $\begin{array}{c}\text { Risk Free } \\
\text { Return }\end{array}$ & $\begin{array}{l}\text { Market } \\
\text { Return }\end{array}$ \\
\hline 2007 & 5.1 & 4.98 & 6.14 & 11.81 & 6.16 & 1.10 & 9.00 & 24.88 \\
\hline 2008 & -41.78 & -33.84 & -56.24 & -34.40 & -0.37 & -2.89 & 11.50 & -58.16 \\
\hline 2009 & 38.83 & 41.45 & 40.05 & 45.62 & 0.00 & 3.06 & 12.50 & 74.562 \\
\hline 2010 & -5.15 & -8.50 & 4.31 & 1.25 & -1.40 & 0.59 & 12.00 & 25.05 \\
\hline 2011 & -11.28 & -11.77 & -24.75 & -16.59 & 0.00 & -0.14 & 9 & -8.19 \\
\hline
\end{tabular}




\begin{tabular}{|c|c|c|c|c|c|c|c|c|}
\hline 2012 & 10.13 & 18.88 & 42.49 & 32.83 & 0.64 & 0.16 & 10 & 3.11 \\
\hline \multirow[t]{2}{*}{ Average } & & & & & & & & \\
\hline & -0.69 & 1.87 & 1.99 & 6.75 & 0.84 & 0.32 & 10.67 & 10.20 \\
\hline \multicolumn{6}{|c|}{ Average of Close-ended Fund } & & & \\
\hline \multicolumn{6}{|c|}{ Average of Open-ended Fund } & & & \\
\hline \multicolumn{6}{|c|}{ Average of Open and Close Funds } & & & \\
\hline & & & & & & & 1.85 & \\
\hline
\end{tabular}

(Table-1)

\subsection{Sortino Measure}

Sortino ratio results show market returns are well from other open and close-ended funds. Open-ended funds performance is better than close-ended funds. Average Sortino ratio of market is -0.03 , open-ended Fund's ratio is -3.36 and close-ended ratio is -6.40 . That shows open-ended fund's performance is overall batter and less risky then close-ended fund's performance and risky. Close-ended Income fund's Sortino ratio is -18.10 , which shows the lowest performance among all close-ended funds in sample. Open-ended income funds Sortino ratio -9.12 is lower among all open-ended fuds but better as compare to close-ended income fund -18.10. Balance close-ended fund sortion ratio -0.72 that show the fund's performance is also low from open-ended balance fund sortino ratio -0.69 .

Equity close-ended fund's sortino ratio -0.39 show performance is well from other balance and income close-ended funds performance but Open-ended equity fund's sortino ratio is -0.29 which show higher performance from close-ended equity fund. Also open-ended equity fund show well performance from all other open-ended fund, KSE and close-ended funds.

The last 6 years Sortino measure result of the overall mutual fund industry on the sample based close-ended and open-ended mutual funds is -4.89 which show lower performance from market KSE -0.03 (Table 2). 


\begin{tabular}{|c|c|c|c|c|}
\hline $\begin{array}{l}\text { Average Returns } \\
\text { 2007-2012 }\end{array}$ & Average Returns of Fund & Excessive Return & Down Side volatility & Sortino Ratio \\
\hline \multicolumn{5}{|c|}{ Close-ended Mutual Fund } \\
\hline Balance Close Fund & -0.69 & -11.69 & 16.34 & -0.72 \\
\hline Equity Close Fund & 1.99 & -9.00 & 23.16 & -0.39 \\
\hline Income Close Fund & 0.84 & -10.16 & 0.56 & -18.10 \\
\hline Average of Close Funds & 0.72 & -10.29 & 13.35 & -6.40 \\
\hline \multicolumn{5}{|c|}{ Open-ended Mutual Fund } \\
\hline Balance Open Fund & 1.87 & -9.13 & 13.17 & -0.69 \\
\hline Equity Open Fund & 6.75 & -4.246 & 14.32 & -0.29 \\
\hline Income Open Fund & 0.32 & -10.68 & 1.17 & -9.12 \\
\hline Average of Open Fund & 2.98 & -8.02 & 9.56 & -3.37 \\
\hline $\begin{array}{l}\text { Average of Open and Close } \\
\text { Funds }\end{array}$ & 1.85 & -9.15 & 11.46 & -4.89 \\
\hline KSE 100 Index & 10.20 & -0.79 & 23.30 & -0.03 \\
\hline
\end{tabular}

(Table-2)

\subsection{Sharpe Measure}

Sharp ratio show the risk adjusted performance of all variables in sample size. Market Sharpe ratio is -0.01 that show better performance as compare to of others close and open-end mutual funds having risk. Average Close-ended Mutual Fund sharp measure is -1.45 that shows better performance as compare to open-ended fund -1.93 over the last six years. The last 6 years Sharp measure result of the overall mutual fund industry on the sample based close-ended and open-ended mutual funds is -1.68 which show lower performance from market KSE -0.01.

Income close-ended fund performance is lower from other close-ended equity and balance funds over last six years and its Sharpe measure result is -3.65. Income open-ended fund Sharp ratio results -5.33 show more risky and lower performance from all funds in sample size and KSE. Equity Open-ended mutual fund performance is better because Sharpe ratio show -0.12. Close-ended equity funds Sharp ratio is -0.23 , which show lower fund performance as compare to equity open-ended fund but better as relative from other balance and income close-ended fund's performance.

Balance open-ended Fund -0.34 performance is lower from open-ended equity -0.12 fund but higher from open-ended income fund ratio -5.33. Balance close-ended Fund -0.43 
performance is lower as compare open-ended balance fund and also from close-ended equity -0.23 fund but higher from close-ended and open-ended income fund ratio performance. Overall best performance among all funds in sample size is equity open-ended fund and worst also open-ended fund of income according to sharp ratio (Table-3).

\begin{tabular}{|c|c|c|c|c|}
\hline $\begin{array}{l}\text { Average Returns } \\
\text { 2007-2012 }\end{array}$ & Average Returns of Fund & Excessive Return & Standard deviation & Sharp Ratio \\
\hline \multicolumn{5}{|c|}{ Close-ended Mutual Fund } \\
\hline Balance Close Fund & -0.69 & -11.36 & 26.58 & -0.43 \\
\hline Equity Close Fund & 1.99 & -8.67 & 37.99 & -0.23 \\
\hline Income Close Fund & 0.84 & -9.83 & 2.69 & -3.65 \\
\hline Average of Close Funds & 0.71 & -9.95 & 22.42 & -1.44 \\
\hline \multicolumn{5}{|c|}{ Open-ended Mutual Fund } \\
\hline Balance Open Fund & 1.87 & -8.79 & 26.20 & -0.34 \\
\hline Equity Open Fund & 6.75 & -3.46 & 29.95 & -0.12 \\
\hline Income Open Fund & 0.32 & -10.35 & 1.94 & -5.33 \\
\hline Average of Open Fund & 2.98 & -7.54 & 19.37 & -1.93 \\
\hline $\begin{array}{l}\text { Average of Open and Close } \\
\text { Funds }\end{array}$ & 1.85 & -8.74 & 20.89 & -1.68 \\
\hline KSE 100 Index & 10.20 & -0.46 & 43.90 & -0.010 \\
\hline
\end{tabular}

(Table-3)

\subsection{Treynor measure}

Systematic risk is measured by Treyoner measure with risk adjusted performance. Open-ended Equity Fund has highest result of Treynor ratio 2.73 that show better performance of fund over per unit of systematic risk among all other open and close-ended funds in sample size. Treynor ratio 0.45 of close-ended equity fund results show better performance with systematic risk among all other close and open-ended funds like balance and equity but not better as compare to open-ended equity fund.

Balance open-ended funds 0.44 Treynor measure more than from close balance -3.33. Income open-ended funds Treynor measure 0.31 shows more systematic risk as compare to close-ended income fund 0.36. All sample based open-ended funds of average result of Treynor measure is 1.16 more than the averages of close-ended funds -0.85 which show close-ended fund have grater systematic risk. Average treynor measure result is 0.15 
including industry of all open-ended and close-ended funds of sample.

The beta of average open-end mutual funds is -25.08 more negative than close -20.67 that show close-ended funds are lower systematic risk. Betas of all close-end funds are lesser then open-ended funds and both funds less than 1 that show market Bata (Table 4).

\begin{tabular}{|c|c|c|c|c|}
\hline $\begin{array}{l}\text { Average Returns } \\
\text { 2007-2012 }\end{array}$ & Average Returns of Fund & Excessive Return & $\boldsymbol{\beta}$ & Traynor Ratio \\
\hline \multicolumn{5}{|c|}{ Close-ended Mutual Fund } \\
\hline Balance Close Fund & -0.69 & -11.36 & 3.40 & -3.33 \\
\hline Equity Close Fund & 1.99 & -8.20 & -28.40 & 0.45 \\
\hline Income Close Fund & 0.84 & -9.37017 & -36.99 & 0.36 \\
\hline Average of Close Funds & 0.71 & -9.64624 & -20.66 & -0.85 \\
\hline \multicolumn{5}{|c|}{ Open-ended Mutual Fund } \\
\hline Balance Open Fund & 1.87 & -8.34 & -29.33 & 0.44 \\
\hline Equity Open Fund & 6.75 & -3.45 & -4.68 & 2.73 \\
\hline Income Open Fund & 0.32 & -10.52 & -41.23 & 0.31 \\
\hline Average of Open Fund & 2.98 & -7.44 & -25.08 & 1.16 \\
\hline $\begin{array}{l}\text { Average of Open and Close } \\
\text { Funds }\end{array}$ & 1.85 & -8.54 & -22.87 & 0.156 \\
\hline KSE 100 Index & 10.20 & -0.458 & 1 & -12.78 \\
\hline
\end{tabular}

(Table 4) 


\section{Ml Macrothink}

International Journal of Accounting and Financial Reporting

ISSN 2162-3082 2015, Vol. 5, No. 1

\subsection{Jensen differential measure}

Jansen measure show open-ended equity fund's its alpha value is -3.92 performances is better not only among all open-ended funds but also from all close-ended funds. It means open-ended equity fund return is less risky than other funds while alpha value of all funds in sample has more negative value than open-ended equity fund. Open-ended balance funs alpha value is -8.89 and close-ended balance funds value is -11.42 which show more risky returns from open-ended funds.

Equity Close-ended fund -8.66 is better from all close-ended fund alpha values like balance -11.42 and income -9.99 , which show that close equity fund is less riskier from others. Income open and close-ended fund alpha values are likely to same -10.40 and -9.99 so risk of both fund same as compare to each others.

Close-ended funds alpha value shows -10.02 more risky than open-ended funds -7.74 . The overall industry of funds in sample size all sample based open and close-ended mutual funds average alpha value is -8.88 . Funds are not showing out performance against market because the alpha value of all sample based funds show negative value. It means all funds earned too little for its risk (or, was too risky for the return) because all funds value are negative (Table $5)$.

\begin{tabular}{|c|c|c|c|c|}
\hline $\begin{array}{l}\text { Average Returns } \\
\text { 2007-2012 }\end{array}$ & $\beta \mathrm{im}$ & $\beta(\mathbf{r m}-\mathbf{r f})$ & $R f+\beta(r m-r f)$ & $\alpha=\operatorname{Ri}-[\operatorname{Rf}+\beta(\mathbf{r m}-\mathbf{r f})]$ \\
\hline \multicolumn{5}{|c|}{ Close-ended Mutual Fund } \\
\hline Balance Close Fund & -0.13 & 0.06 & 10.73 & -11.42 \\
\hline Equity Close Fund & 0.019 & -0.009 & 10.66 & -8.66 \\
\hline Income Close Fund & -0.37 & 0.17 & 10.84 & -9.99 \\
\hline Average of Close Funds & -0.16 & 0.07 & 10.74 & -10.02 \\
\hline \multicolumn{5}{|c|}{ Open-ended Mutual Fund } \\
\hline Balance Open Fund & -0.19 & 0.08 & 10.76 & -8.88 \\
\hline Equity Open Fund & -0.007 & 0.004 & 10.67 & -3.92 \\
\hline Income Open Fund & -0.10 & 0.05 & 10.72 & -10.40 \\
\hline Average of Open Fund & -0.10 & 0.05 & 10.71 & -7.74 \\
\hline $\begin{array}{l}\text { Average of Open an } \\
\text { Close Funds }\end{array}$ & -0.13 & 0.06 & 10.73 & -8.88 \\
\hline
\end{tabular}

(Table-5) 


\section{Macrothink}

International Journal of Accounting and Financial Reporting

ISSN 2162-3082

2015, Vol. 5, No. 1

\subsection{Information Measure}

Good fund management is evaluated with the help of Information measure. Equity open-ended Fund -0.13 performances is better as compared to all open and close-ended funds in the sample and also from equity close-ended fund -0.22. The performance of close-ended balance Fund is lowest in the sample and result of its information measure is -0.41 . But open-ended balance fund information result -0.34 show higher performances than close-ended balance. Income close-ended funds results of information measure is -3.65 show lower performance from close-ended other funds but well from open-ended fund results of information measure -5.33 and income open-ended fund performance below from all other fund in sample size.

The average close-ended funds result of information measure is -0.32 that show lower performance than the open-ended mutual fund results -0.24 . Open-ended funds performance show less risky than close-ended funds. Average result of close and open fund is -0.28 and negative result show that performance of fund is below than market (benchmark) and funds are more risky as compare to market and not management of all fund is not good (Table 6).

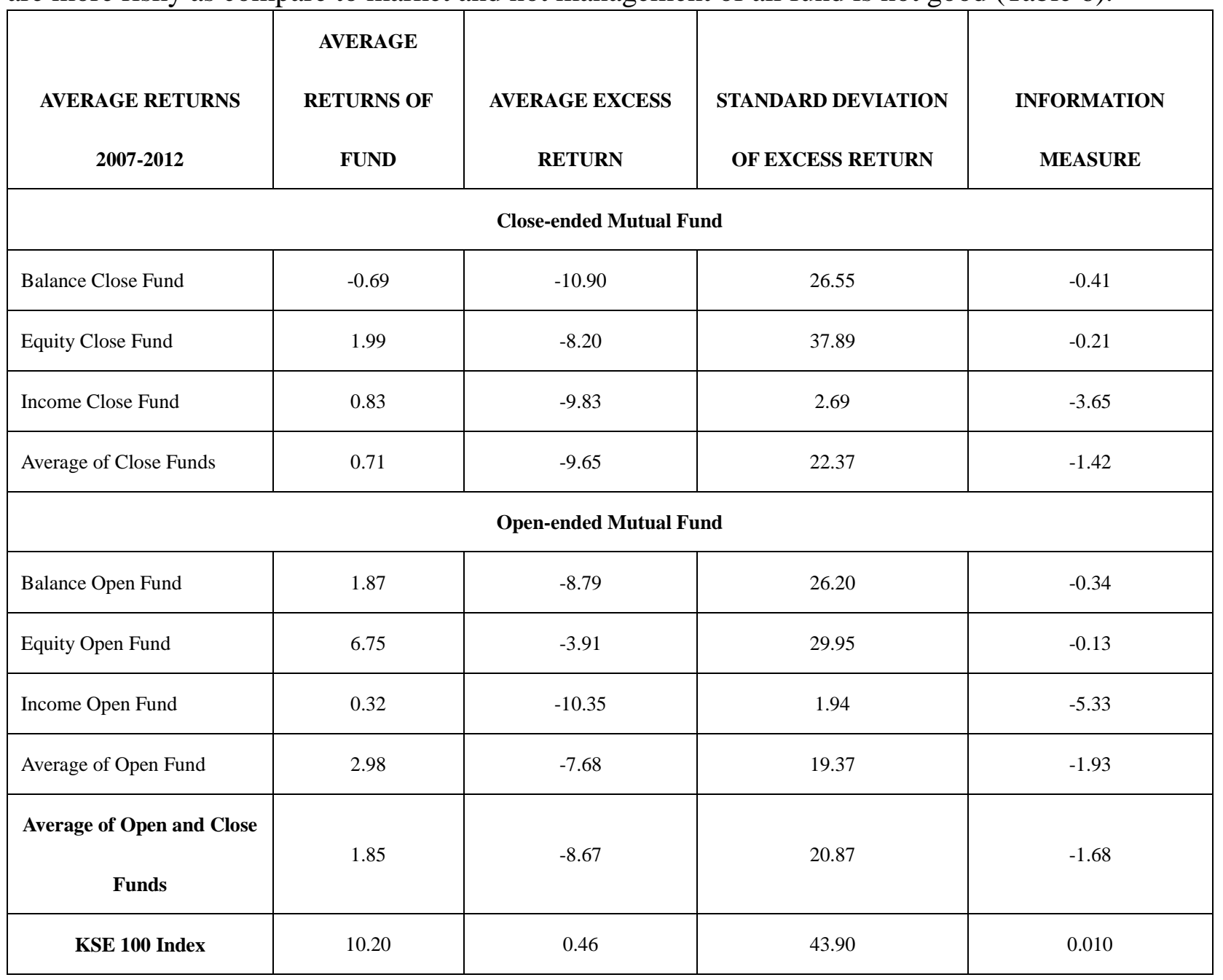

(Table-6) 


\section{Discussion \& Conclusion}

This study evaluates and compares the risk adjusted performance of open and close-ended mutual funds performance from June 2007 to 2012. Analysis is based on open and close-ended mutual funds with risk free rate and KSE returns.

Sortino measure average results of close-ended funds are more negative and riskier than open-ended funds and KSE results better than average result of both open and close-ended funds, but all are negative. That show excess return is less at one unit of down side risk. Sharpe measure average results of open-ended fund more risky due to its more negative results from close-ended fund and KSE. Average sharp measure result of close and open-ended fund show more risky then market, because results are more negative then market. According to Sharp ratio results the overall mutual funds industry not performing well.

Treynor measure depicts that beta value is less than one of all close and open-ended mutual funds so they adopt defensive strategy, not any one fund whose beta is more than one, so any fund types were being not managed aggressively against market movement. Open-ended average results of Treynor measure more than close-ended results. Close-ended funds having lower amount of yield over per unit of market (systematic risk) as compare to open-ended mutual funds. Performance of mutual funds relative to systematic risk is measured with Treynor ratio.

All mutual funds results of Jansan alpha show negative alpha value except one fund. It means mutual fund industry not performing well. Also the information measure show same picture that show other measures. Benchmark performance greater than mutual fund as like KSE or risk free rate. Information measure calculated through excessive return divided by per unit of risk and the overall fund industry result show negative performance which show by information measure.

Market KSE-100 index results of all measure show better performance as compare to mutual fund performance. Mid 2007 to late 2009 a great recession faced by all over the world economies and also faces mutual fund industry in all over the world and also in Pakistan. Mutual fund industry gets speed in 2010 and overall performance batter but in 2011 funds show negative returns. Funds see positive returns in 2012 as far as terminal performance is concerned.

The relationship of risk and return explain by all the measure. Funds investment and different categories wise ranking of ratio are different especially with the preference of risk.

All measure of results show that the fluctuating environment of market changes the ranking of close-ended funds. The negative results of all measures show the unsatisfied performance of these Funds which means that the Fund industry is not at a flourishing stage in Pakistan.

\section{Reference}

Aamir, M., Qayyum, A., Nasir, A., Hussain, S. \& Butt, S. (2011). Closed-ended mutual fund and stock market growth:a case of kse pakistan. European Journal of Social Sciences, 24 (1), 64-70.

Ali, R., \& Qudous, R. (2012). Performance evaluation of mutual funds in Pakistan. Interdisciplinary Journal of Contemporary Research in Business, 3 (9), 1076-1083.

Bilal, N, Syed, M. A. S. \& Safiullah, K. (2011), Performance evaluation of open end and 


\section{Mll Macrothink}

International Journal of Accounting and Financial Reporting ISSN 2162-3082 2015, Vol. 5, No. 1

close end mutual funds in Pakistan. African Journal of Business Management, 5 (28), $11425-11434$

Bryant, L. L. \& Liu, H. C. (2011). Mutual Fund Industry Management Structure, Risk and the Impacts to Shareholders. Global Finance Journal, 5 (7), 124-129.

Carhart, M., (1997). On persistence in mutual fund performance. Journal of Finance, 52 (4), 57-82.

Cheema, M., \& Shah, S. A. (2006) The Role of Mutual Funds and Non-Banking Financial Companies in Corporate Governance in Pakistan. Centre for Management and Economic Research, 8(3), 06-47.

Fama, E. F., \& French, K. R. (1993). Common risk factors in the returns on stocks and bonds. Journal of Financial Economics, 7(3) 3-56.

Gohar, R., Ahmed, S. \& Niazi, U. (2011). Performance comparison of mutual funds in Pakistan. African Journal of Business Management, 5(14), 5583-5593.

Gorman, L. (1991). A study of the relationship between Mutual Fund return and asset size. Review Akron Business and Economic, 22(3), 53-61.

Jensen, M. C. (1968). The Performance of Mutual Funds in the Period 1945-1964. The Journal of Finance, 23(2), 389-416

Khalid, S.I., Abbas, M.Z., \& Shah, D.S. (2010). Performance evaluation of close-ended mutual funds by investment objectives in pakistan's economy. Interdisciplinary Journal, Contemporary Business Research, 193-213.

Mutual Fund Association of Pakistan. Retrieved April, 03, 2013. Website http://mufap.com.pk/pdf/WRMF.pdf/

Mutual funds of Pakistan. Retrieved April, 15, 2013. Website http://www.mutualfundspakistan.com/amc.aspx/.

Nazir, M. S., \& Nawaz, M. M. (2010). The determinants of mutual fund growth in Pakistan. International Research Journal of Finance and Economics, 54 (2), 75-84.

Rauf, A. \& Talat, A. (2009). Performance evaluation of Pakistani mutual funds. Pakistan Journal of Economic, 1-10.

Retrieved August, 12, 2012. http://www.investopedia.com/terms/m/mutualfund.asp/

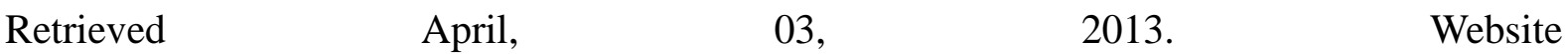
http://www.bloomberg.com/markets/funds/country/pakistan/

Retrieved April, 2013.2 Website http://www,brecorder.com/usiness-a-finance/managed-funds.html

Rida, A. \& Qudous. (2010). Performance evaluation of mutual funds in Pakistan inter jour. Contemporary Business Research, 11 (4), 163-234.

Shah, S.A, \& Hijazi, S.T. (2005). Performance Evaluation of Mutual Funds in Pakistan. Pakistan Economic Development. Review, 863-876.

Sharpe, W.F., (1966). Mutual funds performance. Journal of Business, 119-138.

Sharpe, W. F. (1994). The Sharpe ratio. The Journal of Portfolio Management , 32 (4), 1-19.

Shazia, I. \& Khalid,(2009 ). Performance evaluation of close-ended mutual funds in Pakistan Journal of Finance, 44 (5), 132-623. 